ISSN 2527-9092
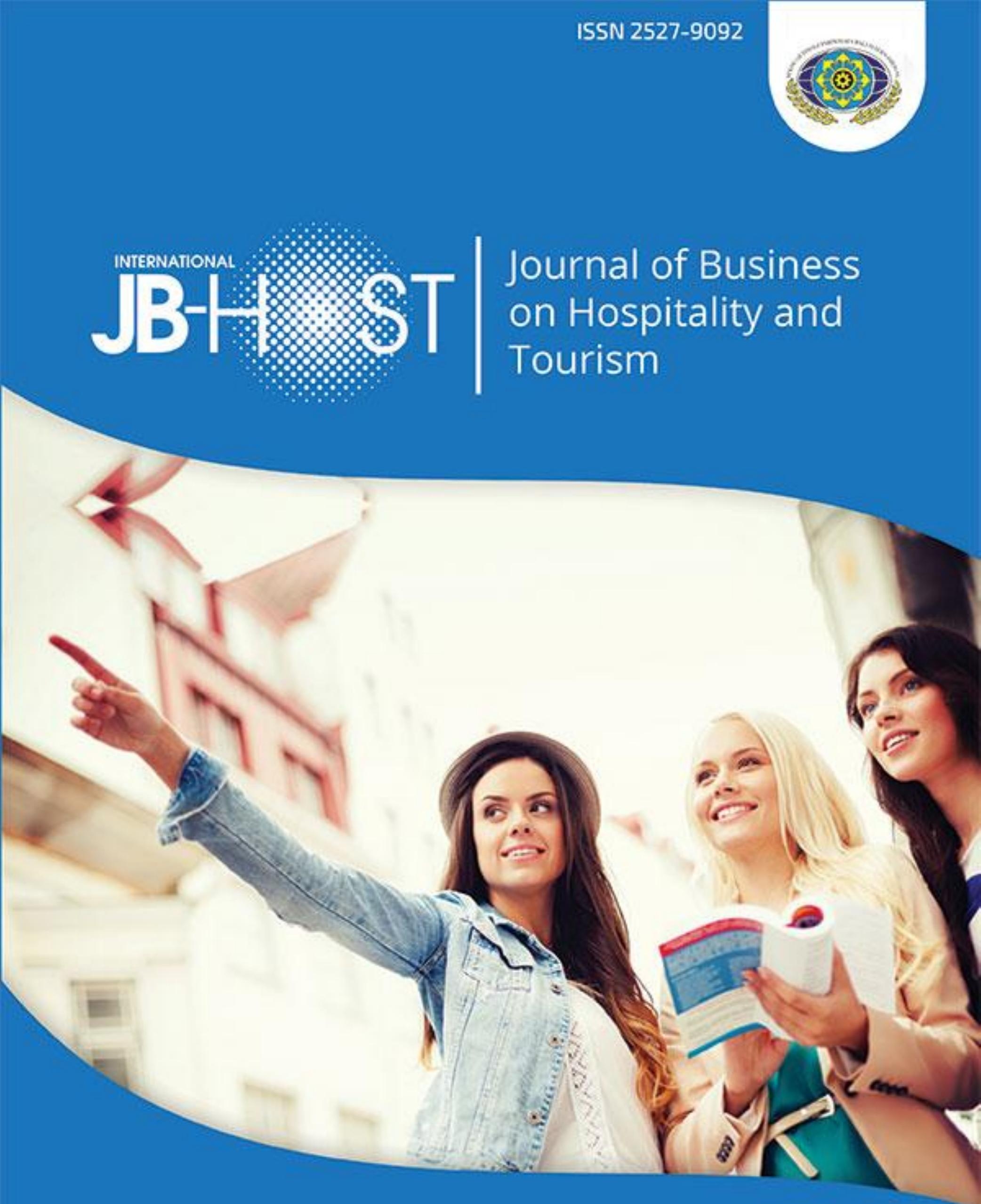

Journal of Business on Hospitality and Tourism

Vol. 5 Issue 2 December 2019 


\title{
JBHOST
}

\section{Journal of Business on Hospitality and Tourism}

\author{
First Published in December 2015
}

ISSN 2527-9092

EISSN: 2527-6921

\begin{abstract}
Published by STPBI. First published in 2015. The journal is intended as a medium for scientific study, research, and critical analysis study of the issues surrounding tourism and hospitality business.
\end{abstract}

Published twice a year in July and December.

Secretariat:

\section{JBHOST}

(Journal of Business on Hospitality and Tourism)

Litabmas STPBI.

Sekolah Tinggi Pariwisata Bali Internasional

Jalan Tari Kecak, No. 12, Gatot Subroto Timur - Bali

Telp : +62 $361-426699$

Fax : +62 $361-426700$

Email : info@jbhost.org humas@stpbi.ac.id

Website: http://jbhost.org

https://dx.doi.org/10.22334/jbhost 
Volume 5 Issue 2

December 2019

\section{EDITORIAL BOARD}

INTERNATIONAL ADVISORY BOARD

Prof. Dr. Enno Schmoll. Jade University, Wilhelmshaven, Germany

\section{EDITOR IN CHIEF}

Dr. Denok Lestari. STPBI, Indonesia

JOURNAL MANAGER

Putu Mega Putra, M.Pd. STPBI, Indonesia

\section{EDITORS}

Ni Made Ayu Sulasmini, S.Pd.,M.Pd.,CHT.,CHE. STPBI, Indonesia Ni Luh Supartini, S.Pd.,M.Pd. STPBI, Indonesia

Dr. Gede Yoga Kharisma Pradana,S.Sos., M.Si. STPBI, Indonesia

\section{INTERNATIONAL REVIEWER}

Prof. Vickneswaran Nair. Taylor's University, Malaysia

Prof.Dr. Theodore Benetatos. IMI, Switzerland

Dr. Qu Xiau. Hongkong Polytechnic University, Hongkong

Dr. Kim Sam. Hongkong Polytechnic University, Hongkong 
Prof. Dr. I Nyoman Dharma Putra, M.Litt. Udayana University, Indonesia

Dr. Devi Kausar. Pancasila University, Indonesia

Dr. I Nyoman Laba. STPBI, Indonesia

Prof. Edgar Allan Dela Cruz Mendoza. University of the Philippines | UPD .

College of Home Economics, Philippines 


\section{ACKNOWLEDGMENTS}

The fifth Journal of Business on Hospitality and Tourism, JBHOST, is finally published. This year JBHOST is published twice a year in July and December. All of the accepted papers were reviewed by our reviewers in order to be included in this journal.

Papers presented are covering the issues on hospitality and tourism development, attraction and destinations, tourism marketing, Event, and Human resources development, and tourism education.

We thank the contributors, the foundation of Yayasan Dharma Widya Ulangun, the Management of STPBI, and JBHOST committee for enabling this publication, JBHOST, Journal of Business on Hospitality and Tourism, Volume 5 Issue 2, to be successfully produced on time.

JBHOST Editorial 


\section{TABLE OF CONTENTS}

BISCUIT FORMULATION WITH SUBSTITUTION OF BROWN RICE FLOUR ......................... 159

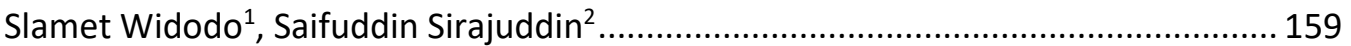

THREE BUCKETS SYSTEM FOR FOOD STREET INDUSTRY. CASE STUDY IN BANDUNG AND

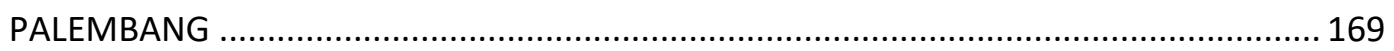

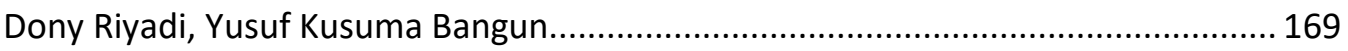

TOURIST PERCEPTION OF TANJUNG DURIAT ECOTOURISM JATIGEDE RESERVOIR AREA

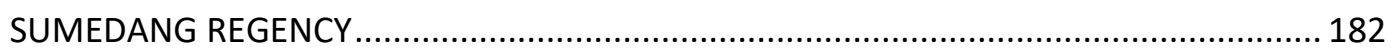

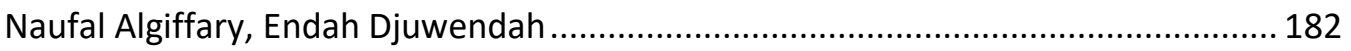

ANALYSIS OF FACTORS AFFECTING GUEST DECISION IN PURCHASE OF ROOM SERVICE IN

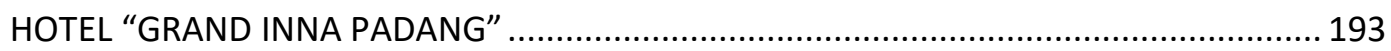

Youmil Abrian, Arif Adrian, Rian Surendra............................................................ 193

ANALYSIS OF FEASIBILITY OF PARK KUMBASARI AS ATTRACTION FRIENDLY TOURISM TO

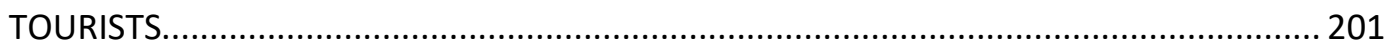

I Gusti Ketut Purnaya ${ }^{1}$, I Made Trisna Semara ${ }^{2}$, I Putu David Adi Saputra ${ }^{3}$................. 201

DECISION MAKING TO VISIT KOPI LUWAK AGROTOURISM (Case Study of Kopi Luwak

Cikole in Cikole Village, Babakan Village, Lembang District) ....................................... 207

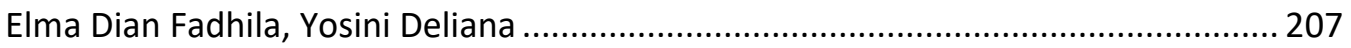

TOURISTS EXPECTATION AND PERCEPTION TOWARD SANGEH TOURISM VILLAGE ...... 218

I Made Bayu Wisnawa ${ }^{1}$, Anak Agung Ratih Wijayanti ${ }^{2}$, Sulistyoadi Jokosaharjo ${ }^{3}$...... 218

THE ROLE OF TOURISM DESTINATION AND HUMAN RESOURCES IN SUSTAINABLE

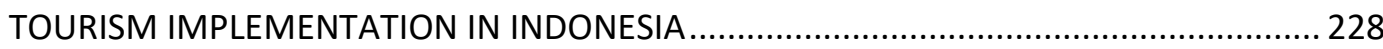

Nyoman Surya Wijaya, S.E.,M.M. Komang Trisna Pratiwi Arcana, S.ST.Par.,M.Par.,

M.Rech, I Wayan Eka Sudarmawan, S.ST.Par., M.M. 228

ECOTOURISM DEVELOPMENT IN SUNGAI JANIAH, AGAM: THE PARADIGMS FROM THE

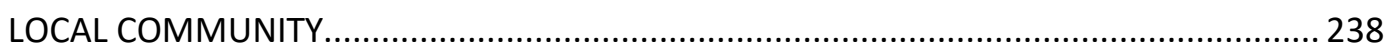

Hendri Azwar, Pasaribu, Heru Pramudia ....................................................................... 238

THE VALUES OF BATANG HARING AS LOCAL WISDOM IN BUILD ING THE SUSTAINABLE COMPETITIVE ADVANTAGE OF TOURISM DESTINATION IN CENTRAL KALIMANTAN..... 249

${ }^{1}$ Daniel Pandu Mau, ${ }^{1}$ Tjokorda Gde Raka Sukawati 249 DEFINING SOCIAL SUSTAINABILITY AND SOCIALLY CONSCIOUS TOURIST IN SUSTAINABLE TOURISM DEVELOPMENT 264 
Agusta Ika Prihanti Nugraheni ${ }^{\mathrm{ab}}$, Tri Kuntoro Priyambodo ${ }^{\mathrm{ac} *}$, Bayu Sutikno ${ }^{\mathrm{a}}$, Hendrie

Adji Kusworo ${ }^{a}$.

TOURIST VILLAGE PORTRAIT (CASE STUDY IN KAMPUNG TAJUR, DESA PASANGGRAHAN, KECAMATAN BOJONG, KABUPATEN PURWAKARTA) ............................................. 277

Iyan Mugni Nugraha, Gunardi Judawinata ...................................................... 277

THE EFFECTS OF SERVICE QUALITY, CUSTOMER PERCEIVED VALUE, AND CUSTOMER SATISFACTION TOWARDS CUSTOMER LOYALTY OF DAMRI TOUR BUS........................ 285

Suci Sandi Wachyuni .............................................................................. 285

FOOD SOUVENIRS FROM BALI - WHAT MATTERS FOR TOURISTS FROM JAKARTA? ..... 298

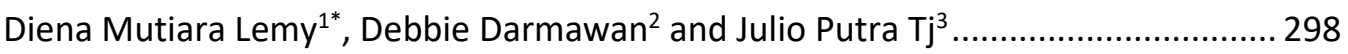
VISITORS PERCEPTION ABOUT THE SAPTA PESONA IMPLEMENTATION IN KAMPUNG

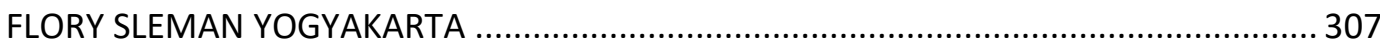

Achmad Septio, Tuti Karyani, Endah Djuwendah. ............................................ 307

RETHINKING THE THEORY OF TOURISM: WHAT IS TOURISM SYSTEM IN THEORETICAL AND EMPIRICAL PERSPECTIVE?

Kadek Wiweka1, Komang Trisna Pratiwi Arcana² 318

THE INFLUENCE OF TOURISM INFORMATION EXPOSURE ON COMMUNITY INVOLVEMENT IN PANGLIPURAN TOURISM VILLAGE 337

I Nengah Laba, I Made Trisna Semara, I Wayan Pantiyasa, Komang Ratih Tujungsari337 


\section{JBHOST}

(Journal of Business on Hospitality and Tourism)

\section{Published by:}

Sekolah Tinggi Pariwisata Bali Internasional

Jalan Tari Kecak, No. 12, Gatot Subroto Timur- Bali

Telp : $+62361-426699$

Fax : $+62361-426700$

Email : info@jbhost.org humas@stpbi.ac.id

Ejournal: http:/jbhost.org

https://dx.doi.org/10.22334/jbhost

\begin{tabular}{|c|c|c|c|c|c|}
\hline JBHOST & Vol.5 & Issue 2 & P. 159-344 & $\begin{array}{c}\text { Denpasar } \\
\text { Dec 2019 }\end{array}$ & $\begin{array}{c}\text { EISSN } \\
2527-6921\end{array}$ \\
\hline
\end{tabular}

